\title{
COMMENT
}

\section{Cherishing family values: let us not let immigration policy harm children}

\author{
From the Pediatric Policy Council ${ }^{1}$ \\ Pediatric Research (2018) 84:149-150; https://doi.org/10.1038/s41390-018-0105-x
}

In early May 2018, the Trump administration introduced a zerotolerance policy to deter the illegal entry of individuals going across the Mexican border into the United States. ${ }^{1}$ This policy resulted in the deliberate, government-sponsored separation of more than 2300 children from their parents over 2 months. ${ }^{2}$ Seven weeks later, following widespread national and international condemnation of this practice, on 20 June 2018, President Trump issued an executive order temporarily ending the separation practice, but leaving the zero-tolerance policy in effect. ${ }^{3}$ Whether this policy achieves the intended administration goals of reducing illegal immigration and/or forcing the drafting of new legislation to address immigration issues remains to be seen. But, based on the extensive knowledge of child development and effects of toxic stress, ${ }^{4,5}$ it is clear that the separation of infants, toddlers, children, and adolescents from their parents will have serious and lasting adverse effects on health. The long-term fate of these children remains an unanswered question, as well.

Immigration is a complex matter affecting many countries around the globe. Unstable and unsafe local conditions, be they from war, cartel activity, or local economic collapse leading to starvation and medical calamity, are triggering individuals across the world to leave their homelands where generations of their ancestors lived. Many of these individuals are in quest for basic sustenance and safety, not a pot of gold. Such migration can lead to an influx of individuals from different ethnic backgrounds into countries, setting up political clashes with the status quo. The support for new immigrants, and the costs to manage immigration, create both economic and social benefits and pressures that are difficult to quantify. As such, policies have been developed in the United States and other countries to manage immigrant influx.

Sadly, over the past decade around the world, the United States, a country that has been the moral compass for the world, has stood alone in recent child separation policies that literally plucked children from their parents' arms. Although this policy is reversed, we need to ask if this sentinel event will cause us as American and the rest of the world to view our role as a compassionate society differently.

One does not need a biologically based argument to support the notion that the family is the fundamental basis of our civilization, and the forced disruption of this bond will have adverse physical and behavioral effects on children, but there is one. ${ }^{6}$ Toxic social-emotional stresses can influence a child's brain development and contribute to lifelong developmental and behavioral disorders, as well as physical ailments including respiratory disorders, infections, and sleep disruption. ${ }^{6}$ These effects will be not just on the current generation, but on the next.
Altered patterns of gene methylation can be seen, ${ }^{7-9}$ forever changing an individual's genetic blueprint. These genetic changes can be passed to the next generation, leading to increased susceptibility for certain diseases.

The psychological trauma of family separation, likewise, will have both short-term and lasting consequences on a child's mental health. Short-term, acute separation triggers anxiety, and depression. ${ }^{4-6,10}$ Separation anxiety, which parents have seen after dropping their child off for the first day of school, is magnified so much more when the child and parent are not reunited by day's end. The isolated child will grow to be at risk for depression and other mental health conditions, including suicide. ${ }^{4,5}$ The isolated child may also grow to have long-term parenting challenges, transmitting the consequences of early separation on to the next generation. There is indeed evidence of the intergenerational impact of parents' unauthorized immigration status on the health of their US citizen children. ${ }^{11}$

Following the separation policy, we need to ask ourselves, what will be the fate of the more than 2300 separated children? Will they ever be reunited with their parents? What will be their fate, when their parents are detained or deported? Will they forever be wards of the United States? This practical question, which should have been addressed before the separation policy was enacted, ${ }^{3}$ is especially pertinent considering the thousands of other immigrant children whose whereabouts under the current administration are now unknown. ${ }^{12}$

In a society that so cherishes family values and our children's future, we need to ask ourselves, why did we enact a familydisrupting policy? Why are we doing something to others that we as Americans know with certainty contradicts our values and our interests-the forced removal of children from their parents and their continued separation?

We need to ask ourselves, what is to prevent us from repeating the same terrible mistake the next time, and the next? Perhaps we should revisit the UN Convention on the Rights of the Child, ${ }^{13}$ which the United States has sadly failed to ratify for over 20 years, and would such adopted principles blunt the power and temptation of the state to use children as pawns. Or perhaps, we will forever see with clarity the painful lesson learned-that we as a society cherish family bonds and will push politics aside and not let policy decisions harm children.

\section{REFERENCES}

1. Gonzales, R. Sessions says 'zero tolerance' for illegal border crossers, vows to divide families. https://www.npr.org/sections/thetwo-way/2018/05/07/

${ }^{1} 1600$ SW Archer Road - Room R1-118, Gainesville, FL 32610-0296, USA

Correspondence: Scott A. Rivkees (srivkees@ufl.edu)

Published online: 18 July 2018 
609225537/sessions-says-zero-tolerance-for-illegal-border-crossers-vows-todivide-families (2018)

2. Lind, D. The Trump administration's separation of families at the border, explained. https://www.vox.com/2018/6/11/17443198/children-immigrantfamilies-separated-parents (2018).

3. Shear, M. D., Goodnough, A. \& Haberman, M. Trump Retreats on Separating Families, but Thousands May Remain Apart (New York Times, 2018).

4. National Scientific Council on the Developing Chlld. Excessive Stress Disrupts the Arhcitecture of the Developing Brain (National Scientific Council on the Developing Chlld, Cambridge, MA, 2014).

5. Battaglia, M. et al. Early childhood trajectories of separation anxiety: Bearing on mental health, academic achievement, and physical health from mid-childhood to preadolescence. Depress Anxiety 34, 918-927 (2017).

6. Lee, D., et al. Systematic review of pediatric health outcomes associated with childhood adversity. BMC Pediatr. 18 https://doi.org/10.1186/s12887-1201811037-12887 (2018).
7. Malan-Muller, S., Seedat, S. \& Hemmings, S. M. Understanding posttraumatic stress disorder: insights from the methylome. Genes. Brain. Behav. 13, 52-68 (2014).

8. Wolf, E. J., et al. Posttraumatic psychopathology and the pace of the epigenetic clock: a longitudinal investigation. Psychol. Med. 13, 1-10 (2018).

9. Wolf, E. J. et al. Traumatic stress and accelerated DNA methylation age: a metaanalysis. Psychoneuroendocrinology 92, 123-134 (2018).

10. Lee, E. E., Martin, A. S., Tu, X., Palmer, B. W. \& Jeste, D. V. Childhood adversity and schizophrenia: the protective role of resilience in mental and physical health and metabolic markers. J. Clin. Psychiatry 79 (2018). pii: $17 \mathrm{~m} 11776$ https://doi.org/ 10.4088/JCP.17m11776.

11. Hainmueller, J. et al. Protecting unauthorized immigrant mothers improves their children's mental health. Science 357, 1041-1044 (2017).

12. McClatchy. Feds have lost nearly 6,000 children in their custody under Trump. http://www.nydailynews.com/news/politics/ny-news-trump-6000-kids-lost-story20180619-story.html (2018). 